\title{
THE DEVELOPMENT OF PUBLIC SPORTS SERVICE \\ SYSTEM IN CENTRAL AND WESTERN REGIONS FROM THE PERSPECTIVE OF NATIONAL HEALTH STRATEGY
}

\author{
O DESENVOLVIMENTO DO SISTEMA PÚBLICO DESERVIÇOS DESPORTIVOS NAS REGIÕES CENTRAL E \\ OCIDENTAL SOB A PERSPECTIVA DA ESTRATÉGIA NACIONAL DE SAÚDE
}

ARTIGo ORIGINAL

Artículo Original

\section{DESARROLLO DEL SISTEMA DE SERVICIOS PÚBLICOS DE DEPORTE EN LA REGIÓN CENTRO - OESTEDESDE LAPERSPECTIVA DE LAESTRATEGIA NACIONAL DESALUD}

\begin{abstract}
Aizeng Li' (D)
(Public Health)

Yanhong Ren² (D)

(Preventive medicine)

Bo Chen 3 (DD

(Basic Medicine)

Hongbo Liu' (DD

(Food hygiene and inspection)

1Department of Physical Education, Henan Polytechnic University, Jiaozuo, Henan, 454003, China.

2. Department of Physical Education, Jiaozuo Teachers College, Jiaozuo, Henan, 454000, China.

3. Sports Department, Henan University of Economics and Law, Zhengzhou, Henan, 450046, China.
\end{abstract}

Correspondence: JiaozuoHenan454003, China. tngydd@163.com

\begin{abstract}
National health is a new requirement for social development in the new era and in the current situation. At present, there is a problem of unbalanced development of public sports service system among various regions in China, especially the large gap between the East and the Midwest. In order to understand the development status of public sports service system in central and western regions from the perspective of national health strategy, this study constructed the evaluation index system of public sports service in central and western regions, and revised the indicators through two rounds of expert survey, and determined the index weight using AHP. On this basis, taking a city in the central and western region to represent public sports development, the validity and rationality of the evaluation model are verified. The research shows that the public sports service system of the city has a good level and the sports service system is relatively perfect, which can meet the diversified needs of residents participating in sports to a certain extent. Therefore, the development momentum of public sports service system in central and western regions is good, but it still needs to further promote the rational allocation of regional sports resources. It is hoped that this study can provide certain reference for the development of public sports service system in central and western regions from the perspective of national health strategy.
\end{abstract}

Keywords: National health; Midwest; public sports; service system; index.

\section{RESUMO}

A saúde nacional é uma nova exigência para o desenvolvimento social na nova era e na situação atual. Atualmente, existe um problema de desenvolvimento desequilibrado do sistema de serviço público de desporto entre várias regiões da China, com sobretudo uma grande lacuna entre as regiões leste e centro-oeste. A fim de compreender o estado de desenvolvimento do sistema de serviço público de desportos nas regiões central e ocidental a partir da Perspectiva da estratégia nacional de saúde, este estudo construiu o sistema de índice de avaliação do serviço público de desporto nas regiões central e ocidental, e revisou os indicadores através de duas rondas de inquéritos especializados, e determinou o peso do índice por meio do o processo hierárquico analítico (Analytic Hierarchy Process - AHP). Nesta base, verificou-se a validade e a racionalidade do modelo de avaliação, tomando uma cidade na região central e ocidental como representativa do desenvolvimento desportivo público. A pesquisa mostra que o sistema público de serviço esportivo da Cidade tem um bom nível e o sistema de serviço desportivo é relativamente perfeito, o que pode atender às necessidades diversificadas dos residentes que praticam esportes, em certa medida. Por conseguinte, o impulso para o desenvolvimento do sistema público de serviços desportivos nas regiões central e ocidental épositivo, mas ainda precisa de promover a alocação racional dos recursos desportivos regionais. Espera-se que este estudo possa fornecer certa referência para o desenvolvimento do sistema de serviço público de desporto nas regiôes centrais e ocidentais, a partir da Perspectiva da estratégia nacional de saúde.

Descritores: Saúde nacional; Centro-oeste; desporto público; sistema de serviços; índice.

\section{RESUMEN}

Resumen: La salud nacional es un nuevo requisito para el desarrollo social en la nueva era y en la situación actual. En la actualidad, existe un problema de desarrollo desequilibrado del sistema de servicios deportivos públicos entre varias regiones de China, especialmente la gran brecha entre el Este y el Medio Oeste. Con el fin de comprender el estado de desarrollo del sistema de servicios deportivos públicos en las regiones central y occidental desde la perspectiva de la estrategia nacional de salud, este estudio construyó el sistema de índices de evaluación del servicio deportivo público en las regiones central y occidental. Con ese sistema revisó los indicadores a través de dos rondas de encuestas entre expertos y determinó el peso del índice utilizando el proceso de jerarquía analítica (PJA). Sobre esta base, tomando una ciudad de la región central y una de la occidental para representar el desarrollo deportivo público, se verificó la vigencia y racionalidad del modelo de evaluación. La investigación muestra que el sistema público de 
servicios deportivos de la ciudad tiene un buen nivel y el sistema de servicios deportivos es relativamente perfecto, lo que puede satisfacer las diversas necesidades de los residentes que participan en deportes. Por lo tanto, el desarrollo del sistema de servicios deportivos públicos en las regiones central y occidental es bueno, pero aún debe promover más la asignación racional de los recursos deportivos regionales. Se espera que este estudio pueda proporcionar una referencia para el desarrollo del sistema público de servicios deportivos en las regiones central y occidental desde la perspectiva de la estrategia nacional de salud.

Descriptores: Salud nacional; Centro - oeste; deporte público; sistema de servicios; indicadores.

\section{INTRODUCTION}

Since entering the new era, China's economic and social development has been great, people in the pursuit of material life, but also more and more attention to health. ${ }^{1}$ Without the health of the whole people, there will be no well-off society in an all-round way. This is the favorable spur of General Secretary Xi on the promotion of the health of the whole people in China under the new situation, and the spiritual guidance for promoting the all-round development and progress of China's sports cause. National health refers to that all the people are in a general health level. The means to ensure the health of the whole people include popularizing the concept of healthy life, improving health security, optimizing health services, developing healthy environment and developing health industry. Among them, improving the public sports service system is one of the most important ways to ensure national health. ${ }^{2}$ Public sports service is an important part of the public service system, which is systematic, public and service. At present, there is an imbalance in the development of public sports services among various regions in China, especially there is a large gap between the East and the Midwest. ${ }^{3}$ From the perspective of the development reality of the central and western regions, there are some problems, such as insufficient public sports facilities, relatively small coverage, unbalanced distribution of sports service resources, and relatively lagging organizational system construction. However, with the vigorous support of the state to the central and western regions, these problems are gradually improving. The central and western regions need to constantly strengthen and improve the public sports service system, so as to provide protection for the health of the whole people.

It can be seen that research at home and abroad mainly involves the national health and the status quo of public sports, in which the national health is mainly guaranteed by the medical system, and the current situation of sports is mainly based on questionnaire survey and field investigation, and the research is less involved in the study of public sports from the perspective of national health. In view of this, this study analyzes the development of public sports service system in central and western regions from the perspective of national health strategy.

\section{Influence and development factors of public sports authorities}

This study takes the public sports service system of a city located in the western region as an example to study the factors affecting its development, mainly through the random investigation of the public sports department in charge of the city. The western city has a relatively perfect and mature public sports service system, which can be regarded as a typical representative of the development of public sports service in central and Western China from the perspective of national health strategy. According to the above contents, this study has been two rounds of expert evaluation, and the final evaluation index of public sports service system has been determined, and the corresponding index weight is obtained through calculation. The weight of the selected example index is shown in Figure 1. ${ }^{4}$
As this study takes the public sports service resources of the city as the main research object, the secondary index weight is calculated as shown in the figure above. As can be seen from the figure, the index weight of venues and facilities of public sports service resources is 0.2701 , the weight of information supply index of service resources is 0.2538 , the weight of fitness guidance index of service resources is 0.2227 , and the weight of activity organization index of service resources is 0.2534 . The index weight of public sports service resources is 0.2631 , which indicates that service resources play an important role in the development of public sports service system.

Figure 2 shows the public sports projects planned by the city under the strategic perspective of national health. It can be seen from the figure that the public sports service system of the city contains a variety of rich sports, mainly indoor sports, including a variety of ball games and swimming, which can provide a variety of sports options for the city's residents. Three managers and two staff members of the public sports department and 10 residents with fitness habits were randomly

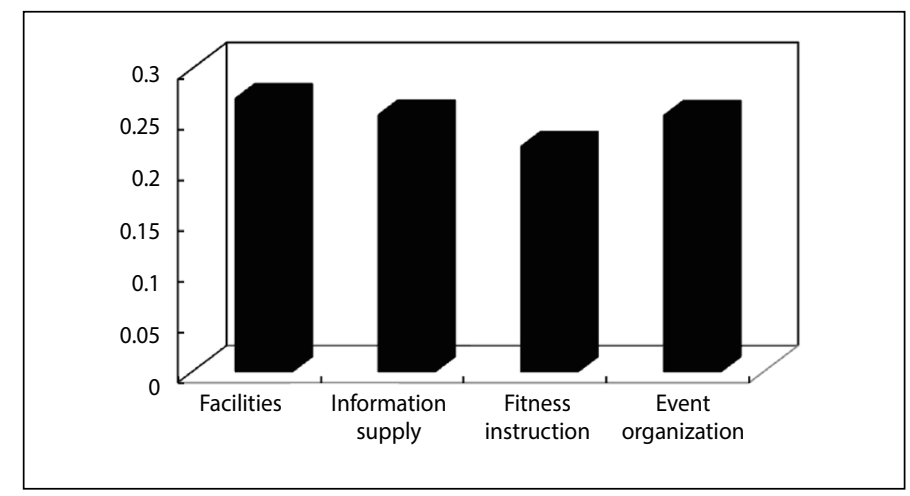

Figure 1. Service resource evaluation index weights.

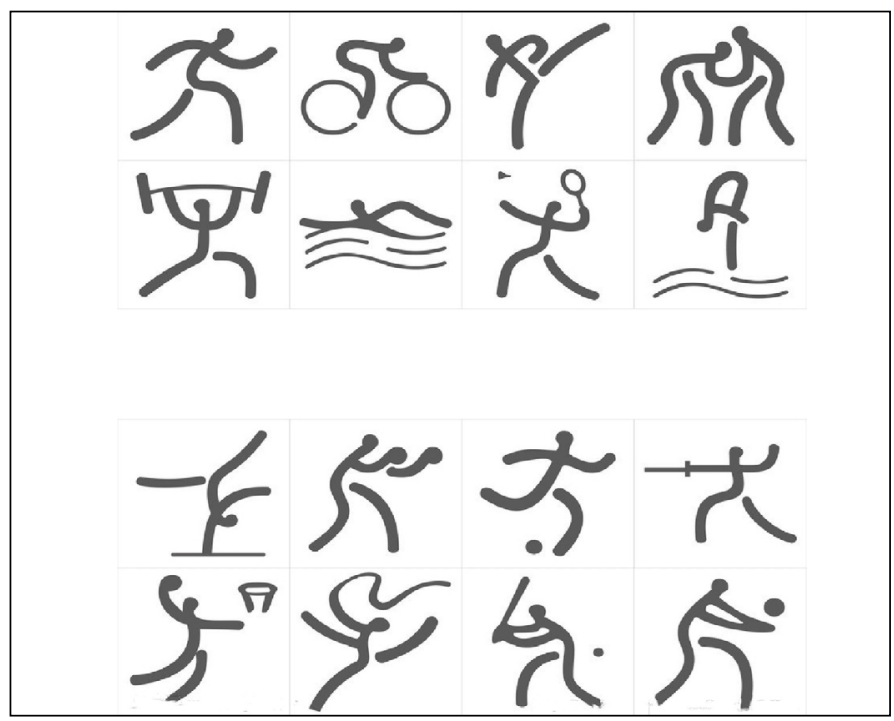

Figure 2. Urban public sports project display. 
selected to score the two-level indicators of the city's public sports service system according to the actual situation, and the main scores were excellent, excellent, good, medium and poor. The corresponding scoring results are shown in Table 1.

Table 1 shows the rating results of the public sports service system indicators of the city by relevant personnel, among which a11-a44 represents each secondary index. The second level indicators of service resources are venues and equipment, information supply, sports guidance and activity organization; the guarantee support of public sports service system includes four secondary indicators, namely, policies and regulations, capital investment, public opinion propaganda and popular science training; the social benefits of public sports service system include four secondary indicators, namely sports population, talent training, community indicators and sports Quality monitoring and feedback; supervision system of public sports service system includes four secondary indicators, namely administrative supervision, resource supervision and publicity, implementation supervision and evaluation and improvement. It can be seen from the table that the grade of each secondary index is above average, and the grade of less evaluation index is poor. Only a few evaluation indexes such as activity organization, policies and regulations, sports population are rated as poor, accounting for less than 0.1 . It can be seen that the city's public sports service is relatively complete, and the evaluation is high.

Figure 3 shows the result of index grade proportion obtained from the above table. It can be seen from the figure that 34\% of the city's public sports service system is excellent, $30 \%$ of the city's public service system is excellent, and 20\%, 15\% and 1\% of the city's public service system is rated as good, medium and poor, respectively The results show that the urban public sports service system in the central and western regions develops well. Furthermore, fuzzy comprehensive evaluation is carried out on the index. Taking A1 as an example, the membership degree R1 can be obtained according to the score table.

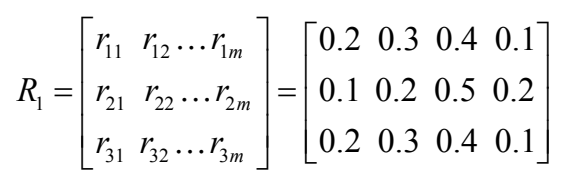

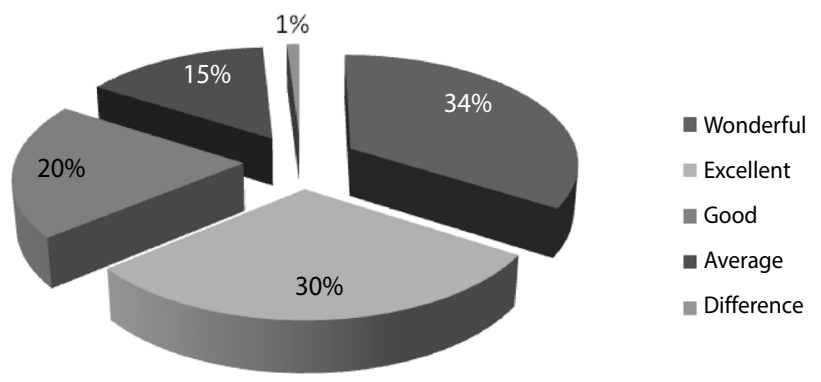

Figure 3. Proportion of indicator levels.

In the same way, the membership degree corresponding to A2, A3 and A4 is obtained, and the fuzzy comprehensive evaluation of the indicators is carried out as follows.

$$
\begin{aligned}
& A=A_{i} * R_{i}=\left(A_{1}, A_{2}, A_{3}, A_{4}\right) *\left(R_{1}, R_{2}, R_{3}, R_{4}\right) \\
& =(0.2057,0.2437,0.3213,0.0992,0.0116)
\end{aligned}
$$

According to the principle of maximum membership, we can get that the public sports service system of the city is equivalent to good, has a good momentum of development, and can meet the multiple needs of the city residents to participate in sports to a certain extent. However, there are still problems in the development of public sports service system in the central and western regions, which needs to further promote the rational allocation of sports resources.

\section{CONCLUSIONS}

In the strategic perspective of national health, continuous improvement of the public sports service system in the central and western regions is the fundamental guarantee to strengthen the residents physical fitness in the central and western regions. This study constructs the evaluation index of public sports service system in central and western regions from the perspective of national health strategy, and modifies the index through two rounds of expert questionnaire survey. At the same time, the fuzzy comprehensive evaluation method is used to evaluate the public sports service system in central and Western China under the health strategy. On this basis, taking a city in central and Western China as an example, the effectiveness of the

\begin{tabular}{|c|c|c|c|c|c|c|c|c|c|c|}
\hline \multirow[b]{2}{*}{ Index number } & \multicolumn{2}{|c|}{ Wonderful } & \multicolumn{2}{|c|}{ Excellent } & \multicolumn{2}{|c|}{ Good } & \multicolumn{2}{|c|}{ Average } & \multicolumn{2}{|c|}{ Difference } \\
\hline & $\begin{array}{c}\text { Number of } \\
\text { people }\end{array}$ & proportion & $\begin{array}{c}\text { Number of } \\
\text { people }\end{array}$ & proportion & $\begin{array}{c}\text { Number of } \\
\text { people }\end{array}$ & proportion & $\begin{array}{c}\text { Number of } \\
\text { people }\end{array}$ & proportion & $\begin{array}{c}\text { Number of } \\
\text { people }\end{array}$ & proportion \\
\hline A11 & 4 & 0.27 & 3 & 0.2 & 6 & 0.4 & 2 & 0.13 & 0 & 0 \\
\hline $\mathrm{A} 12$ & 3 & 0.2 & 5 & 0.33 & 4 & 0.27 & 3 & 0.2 & 0 & 0 \\
\hline $\mathrm{A} 13$ & 5 & 0.33 & 4 & 0.27 & 3 & 0.2 & 3 & 0.2 & 0 & 0 \\
\hline A14 & 3 & 0.2 & 4 & 0.27 & 4 & 0.27 & 3 & 0.2 & 1 & 0.06 \\
\hline $\mathrm{A} 21$ & 4 & 0.27 & 5 & 0.33 & 3 & 0.2 & 2 & 0.14 & 1 & 0.06 \\
\hline A22 & 5 & 0.33 & 3 & 0.2 & 3 & 0.2 & 4 & 0.27 & 0 & 0 \\
\hline A23 & 3 & 0.2 & 3 & 0.2 & 4 & 0.27 & 5 & 0.33 & 0 & 0 \\
\hline A24 & 6 & 0.4 & 2 & 0.13 & 3 & 0.2 & 4 & 0.27 & 0 & 0 \\
\hline A31 & 5 & 0.33 & 4 & 0.27 & 2 & 0.13 & 2 & 0.13 & 2 & 0.13 \\
\hline $\mathrm{A} 32$ & 7 & 0.47 & 4 & 0.27 & 2 & 0.13 & 2 & 0.13 & 0 & 0 \\
\hline A33 & 6 & 0.4 & 5 & 0.33 & 2 & 0.13 & 1 & 0.07 & 1 & 0.07 \\
\hline A34 & 6 & 0.4 & 4 & 0.27 & 4 & 0.27 & 1 & 0.07 & 0 & 0 \\
\hline A41 & 4 & 0.27 & 3 & 0.2 & 5 & 0.33 & 2 & 0.13 & 1 & 0.07 \\
\hline A42 & 5 & 0.33 & 2 & 0.13 & 6 & 0.4 & 2 & 0.13 & 1 & 0.07 \\
\hline A43 & 6 & 0.4 & 4 & 0.27 & 3 & 0.2 & 2 & 0.13 & 0 & 0 \\
\hline A44 & 5 & 0.33 & 3 & 0.2 & 4 & 0.27 & 3 & 0.2 & 0 & 0 \\
\hline
\end{tabular}
evaluation model is verified. The results show that the index weight

Table 1. Evaluation results of service resource level. 
of service resources is 0.2631 , indicating that service resources play an important role in the development of public sports service system. At the same time, the index grade evaluation of public sports service system of the city is basically good, which shows that the public sports service of the city is relatively complete, and the evaluation is high, which can meet the diversified needs of residents participating in sports to a certain extent. The development momentum of urban public sports service system in central and western regions is good, but the development of public sports service system in central and western regions still exists. In the problem, we need to further promote the rational allocation of public sports resources. This study can verify the effectiveness of the comprehensive evaluation model of public service system, but due to the limited data, its wide applicability needs further study.

\section{ACKNOWLEDGEMENT}

The study was supported by "Research on the Standardization of Marathon Service, the National Social Science Fund of China, 2018 (Grant No.18BTY033)".

All authors declare no potential conflict of interest related to this article

AUTHORS' CONTRIBUTIONS: The author has completed the writing of the article or the critical review of its knowledge content. This paper can be used as the final draft of the manuscript. Each author has made an important personal contribution to this manuscript.. Hongbo Liu; aizeng Li: writing and execution. Yanhong Ren: data analysis. Knowledge of articles and articles: Comments on Chen.

\section{REFERENCES}

1. Stephen D. Threats to universal health care. Construction \& Building Materials. 2015; 93(54):360-370.

2. Liu HC, Guo JQ, Xu QE. Correlation Analysis on Environmental Factors Influencing the Development of Urban and Rural Public Sports Equalization Service in South Jiangsu Province. Sports Science: English Version. 2017; 43(5):215-218.
3. Zhang Z, Guo JQ. Research on the Causes of Hindering the Performance of Campus Sports Resources in Public Sports Service. Sports Science: English Version. 2017; 12(5):231-234.

4. Cseh A, Koford BC, Phelps RT. Hospital Utilization and Universal Health Insurance Coverage: Evidence from the Massachusetts Health Care Reform Act. Appl Health Econ Health Policy. 2015; 13(6):627-35. 